Discourse and Communication for Sustainable Education, vol. 10, no. 1, pp. 47-62, 2019

\title{
Towards a Sustainable Future? The EU Policies Concerning Plastics and Their Didactical Potential for Primary and Secondary Teaching
}

\author{
Ulrich Kerscher \\ University of Augsburg, Augsburg, Germany
}

\begin{abstract}
Plastic, plastic waste and marine litter indisputably is one of the key environmental issues of the $21^{\text {st }}$ century. The already existing amount of accumulated marine litter, the high quantity of plastic waste escaping from waste management streams every year in combination with the low recycling rates for plastic and the missing awareness of the consumer for sustainable consumption pose a permanent threat to the ecosystem, biodiversity and human health. What is more, as economic and ecological interests strongly deviate from each other, the transformation of this status quo towards a more sustainable future will take place very slowly. Against this background, this paper will shortly outline the multitude of problems connected to plastic products throughout a product's lifecycle and introduce the idea of a circular economy. On this basis, the paper will critically analyze the strategy papers and the ongoing legislation of the EU introduced to solve these problems and to realize the transformation process of the EU-economy towards a circular economy from a sustainable development point of view. On the one hand, awareness raising is one main strategy of the EU to achieve this transformation, on the other hand, educational institutions are not specifically mentioned by the EU. In order to address this shortcoming, the paper will constitute the teaching principle global development politics / education for sustainable development as one measure to increase consumers' awareness and sustainable consumption. In general, this paper will proof that the topical area plastics can fruitfully be implemented at German schools for primary and secondary education in order to strengthen the education for sustainable development. Keywords: education for sustainable development, global development politics, plastic waste, maritime litter, circular economy, recycling, European Commission.
\end{abstract}

Plastic, Plastic Waste and Maritime Litter

"If we don't change the way we produce plastic, there will be more plastic than fish in our oceans by 2050. We must stop plastic getting into our water, our food and even our bodies" (EC, 2013). 
This quote by Frans Timmermans, EU Vice-President and leading candidate of the European Social Democrats for the EU Elections in 2019, may be an exaggeration, nevertheless, it still points out the severity of the problem Europe and the whole world is facing concerning plastic waste, marine litter and the consequences caused for the environment and human health.

The problem of plastic is of a three-fold nature: Firstly, there are already approximately 150 million tons of macro- and microplastic in the oceans of the world. Every year further ten million tons of plastic are predicted to escape the waste management streams and accumulate in our environment, usually as marine litter. There are already large amounts of debris in the seas and oceans. In the long run, this will potentially lead to severe impacts on the general eco-system and human health. Studies already conclusively show that via the food chain, microplastic finds its way into the human body. Furthermore, marine animals die of too much plastic in their stomach or are injured and killed by entanglement. Moreover, increasing amounts of plastic waste and marine litter also lead to air, water and soil pollution, to adverse economic effects e.g. on the tourism industry and to the loss of aesthetic value of landscape (EC, 2018a).

Secondly, just a fractional amount of the plastic which does not escape the waste management streams is recycled. Generally, there is still significant room for improvement concerning waste management, recycling and the re-use of secondary raw materials. What is more, there are significant differences among member states and across waste streams. Between 2008 and 2016, EU recycling rates for municipal waste increased from $37 \%$ to $46 \%$. But for plastic packaging the average recycling rate in the EU is significantly lower, at $40 \%$. For plastic in general the recycling rate has not yet reached even the $30 \%$ rate (EC, $2018 \mathrm{~b})$. Seen from the point of view of sustainable development, the ongoing accumulation of plastic waste in our environment and the low overall recycling rate for plastics are causes for alarm as they perpetuate and amplify the problems mentioned above.

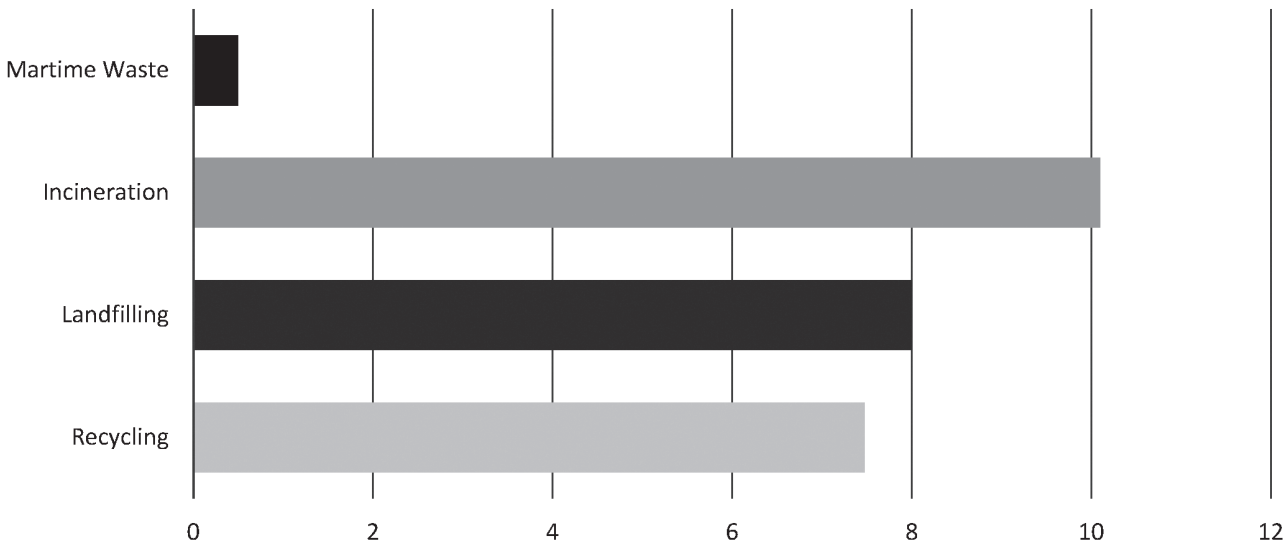

Figure 1. Treatment of plastic waste in the EU in million tons per year (Eurostat / EC, 2018a)

The accumulation of waste and the comparatively low recycling rate of plastic packaging and plastics in general are just one side of a very toxic medal. The other side of this medal is that roughly further 25 million tons of plastic waste are produced in the 
EU every year. Overall less than $30 \%$ are recycled. The other $70 \%$ are either landfilled $(31 \%)$ or incinerated $(39 \%)$. Moreover, large amounts of unrecycled plastic leave the EU to be treated in third countries with much lower environmental standards and recycling techniques (EC, 2018a). Landfilling, incineration and the export of unrecycled plastic waste cannot be seen as sustainable alternatives to recycling and will directly or indirectly have negative consequences for the environment and human health. The per capita data for municipal waste also show that the majority of municipal waste is still either landfilled or incinerated. (EC, 2018b)

Thirdly, the main reason for the low recycling rate of plastic products is the way plastic and plastic products are designed and produced today. Producers of plastic, plastic products and packaging do not have any incentives to consider the possibilities of re-using and recycling their products when they design and produce them. Still in 2019 economic and ecological interests are diametrically opposed. At the moment recycling and reusability means increasing costs for the plastic industry. Plastics are made from a wide range of polymers and are usually highly customized, with specific additives to meet functional and aesthetic requirements. This chemical diversity complicates the recycling process, makes waste management more expensive and affects the quality and value of recycled plastic negatively. Without significant change, the plastic industry will keep producing non-recyclable products and the quantity and quality of secondary raw materials will remain low. Adding to this, the demand for recycled plastics today only accounts for around $6 \%$ of the plastic demand in Europe. This combination of factors prevents investors and the recycling industry from investing money in innovation and the modernization of the recycling industry (EC, 2018a).

\section{Single-Use Plastic Bags - The (Former) Symbol of Our 'Throw-Away Society'}

Overall 98.6 billion plastic bags were consumed EU-wide in 2013; that meant an average of 198 bags per EU citizen. Looking at these numbers, one could say that the plastic bag is the symbol of our throw-away society and unsustainable lifestyles. The biggest environmental problem of plastic bags and plastic in general is their proliferation in the environment; they take thousands of years to decompose. As said before, they easily escape the waste management streams and accumulate in our environment, often as marine litter (EC, 2015a).

In October 2013 the European Commission initiated a public consultation targeting the question How can we reduce marine litter? Its overall aim was to explore measures that could be undertaken by, among others, consumers, retailers, the plastic industry, shipping and fishing companies, NGOs, national governments and EU policy-makers to reduce the presence and impact of marine litter. The results included options such as avoiding the consumption of single use plastic bags and plastic bottles, awareness-raising, clean-up actions and setting reduction targets at national or local level (EC, 2013).

The first legislative outcome of this public consultation concerning plastics was a directive to reduce the consumption of lightweight plastic bags by the European Commission. Light weight plastic bags are carriers with a thickness below $0.05 \mathrm{~mm}$. This threshold is supposed to ensure higher reuse of thicker carriers and lower littering rates. The directive was proposed in November 2013 and passed by the European Parliament in April 2015. Officially the bill was an amendment to the Packaging and Packaging Waste Directive. Concerning prevention, the amendment requires member states to 
take measures to reduce the consumption of lightweight plastic bags by using economic instruments such as taxes or levies, national reduction targets and marketing restrictions. The explanatory statement of the directive also mentions awareness-raising and educational programs (EC, 2015a). Article 1 of the directive stipulates that either "the annual consumption level does not exceed 90 lightweight plastic carrier bags per person by $31^{\text {st }}$ December 2019 and 40 lightweight plastic carrier bags per person by $31^{\text {st }}$ December 2025 [...]" (EC, 2015a), or "the adoption of instruments ensuring that, by $31^{\text {st }}$ December 2018, lightweight plastic carrier bags are not provided free of charge at the point of sale of goods or products [...]"(EC, 2015a).

Generally speaking, the plastic bag directive is in line with the EU Waste Framework Directive published in 2008. In accordance with the EU-Waste Management Hierarchy the directive aims at the prevention and the reduction of the consumption of plastic bags. The Waste Management Hierarchy introduces a priority order to be applied for waste legislation and policy of the EU Member States (EC, 2008).

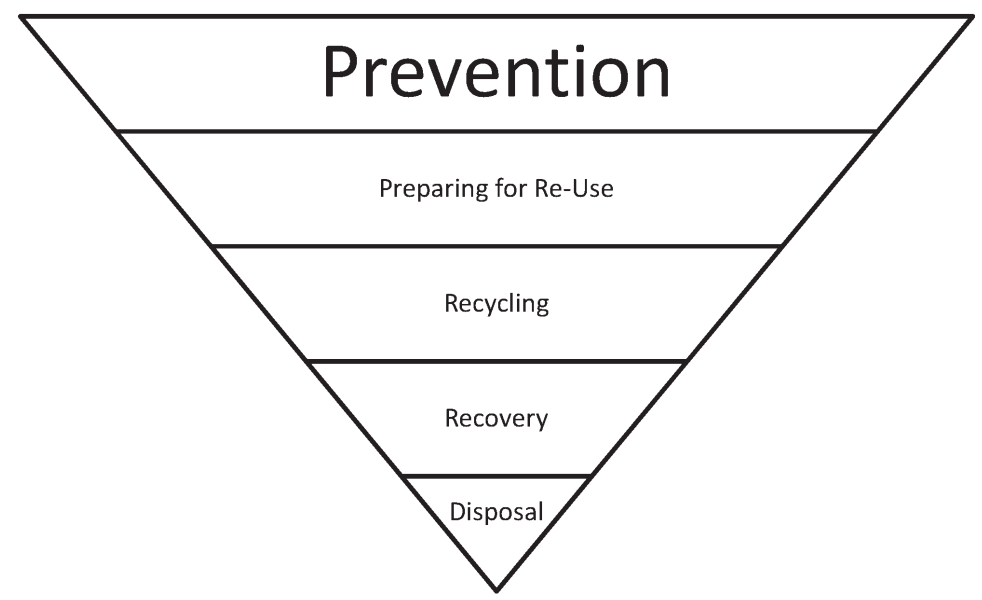

Figure 2. The EU-waste management hierarchy (EC, 2008)

From an environmental point of view, the directive follows the precautionary principle; the polluter pays principle and the extended producer responsibility are not applied. Moreover, the directive relies more on economic measures such as fees, than on awareness-raising strategies to change the consumption patterns of consumers.

Bottom line, the directive was a first and well-meant step into to the right direction. But it was by far not enough to solve the largescale problem. Plastic bags are just one of many sources of marine waste, there are no clear-cut rules for the member states of how to implement the amendment and the directive contains several other loopholes. Hence, as the plastic bag can be seen as a symbol of the throw-away society, this amendment can be seen as symbolic politics.

\section{Closing the Loop - An EU Action Plan for the Circular Economy}

The first comprehensive and strategic approach to solve the largescale problem of plastic waste and marine litter was introduced by the European Commission on $2^{\text {nd }}$ December 2015. The Commission released a communication called Closing the loop- 
An EU Action plan for the Circular Economy. This action plan can be seen as a long term strategy paper without legislative significance of their own. The measures proposed need to be realized in single legislative steps and implemented by the national states.

The general goal of the action plan is to try to accelerate the transition of the EU and the whole world towards a circular economy, increase global competitiveness of the EU economy, promote sustainable economic growth and generate new jobs. Very generally speaking the Commission defines a circular economy as an economy "where the value of products, materials and resources is maintained in the economy for as long as possible, and the generation of waste minimized [...]" (EC, 2015b). This very general definition alone makes clear that a circular economy is not compatible with single use products usually made of plastic, low recycling rates and resources escaping the waste management stream.

In the strategy paper, Brussels identifies plastics as one of five priority areas where to specifically accelerate the transition of their value and production chain towards a more circular process. The other four sectors are food waste, critical raw materials, construction and demolition, biomass and bio-based materials. These five areas have to solve specific challenges concerning the transformation towards a circular economy. Reasons are the specificities of their product- or value-chains, their environmental footprint or their dependency on (raw) materials from outside Europe. Following the title, Brussels wants to 'close the loop' of a product's lifecycle from production and consumption, over repair and remanufacturing, to waste management and marketing as secondary raw materials. As plastics, plastic waste and marine litter is a complex and important issue, the Commission announced a specific strategy focusing on the challenges posed by plastics throughout the value chain. Brussels wanted to take the entire life-cycle into account (EC, 2015b).

By setting 54 measures for 'closing the loop', this action plan for a circular economy is "an essential contribution to the EU's efforts to develop a sustainable, low carbon, resource efficient and competitive economy" (EC, 2015b). The action plan is also said to be "instrumental in reaching the Sustainable Development Goals (SDGs) by 2030 [...] (EC, 2015b).

The circular economy targets all phases of a product's life cycle. Firstly, both the design phase and the production processes have big impact on resource use, the recyclability and reusability of the product and, in reverse, also on waste generation or prevention. It is already this early phase of a product's lifecycle that is decisive for the circular potential of the product. From an economic point of view, however, to transform and innovate this first phase does not yet seem profitable for the economy.

Secondly, the consumption phase is vital for preventing and reducing the generation of household waste. Every single consumer can support or hamper the transition towards a circular economy. Only if profound alterations in the consumption patterns and recycling efforts of the consumers towards sufficiency can be achieved, the transformation towards a circular economy as a whole is possible.

Thirdly, waste management plays a crucial role in establishing a circular economy. It is in this phase where it is determined how the waste hierarchy of the EU is put into practice. In theory, there is a priority order from prevention, preparation for re-use, recycling and disposal such as landfilling. Lastly, in a circular economy recycled materials are injected back into the economy as new materials. Waste management practices have a direct impact on the quantity and quality of secondary raw materials. At present, 
these secondary materials just account for a small proportion of the materials used in the EU. By its very nature, a circular economy is supposed to increase this rate (EC, 2015b).

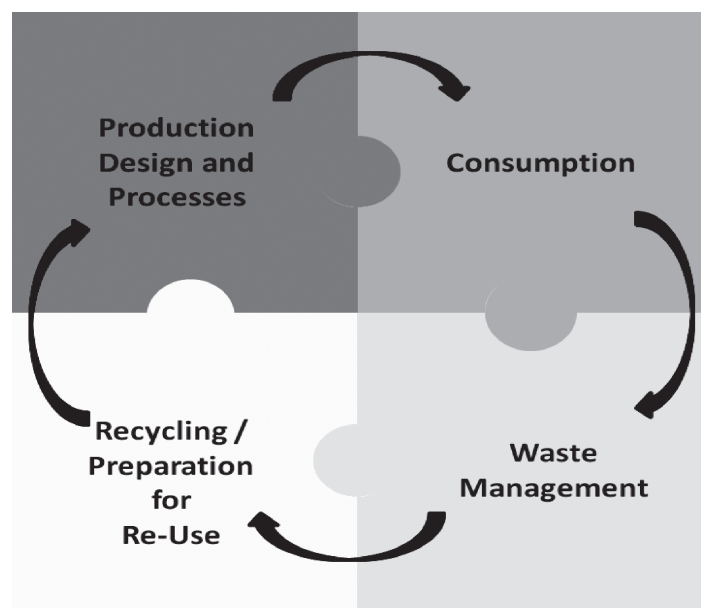

Figure 3. Conceptualization of the circular economy (EC, 2015b)

It is the interplay, the interconnection and the repetition of the four phases of the life of a product which is fundamental for the idea of a circular economy. Especially the last step, the re-use of recycled materials as secondary raw materials, manifests the principle of operation of a circular economy. To successfully inject waste back into the economy as secondary raw materials all four phases have to be geared to each other. As the transition to a circular economy is a systemic change, the action plan introduces actions aiming at each phase of the value chain and the priority areas mentioned above. Furthermore, Brussels also puts forward horizontal measures and a monitoring scheme in order to create "the conditions under which a circular economy can flourish and resources can be mobilized" (EC, 2015b).

Table 1

Overview of the EU Action Plan for a Circular Economy (EC, 2015b)

\begin{tabular}{|c|c|c|}
\hline Phase & Actions & $\begin{array}{l}\text { Principle / } \\
\text { Strategy }\end{array}$ \\
\hline \multirow[t]{2}{*}{$\begin{array}{l}\text { Production } \\
\text { Design }\end{array}$} & $\begin{array}{l}\text { - Improvement of reparability, durability, upgradability } \\
\text { and recyclability of products }\end{array}$ & Efficiency \\
\hline & $\begin{array}{l}\text { - Extended producer responsibility: Economic incentives } \\
\text { for improved product design on the basis of the end-of-life } \\
\text { costs of products paid by the producer }\end{array}$ & $\begin{array}{l}\text { Polluter Pays / } \\
\text { Consistency }\end{array}$ \\
\hline \multirow{3}{*}{$\begin{array}{l}\text { Production } \\
\text { Processes }\end{array}$} & - Global promotion of sustainable sourcing of raw materials & Efficiency \\
\hline & - Fostering of the cooperation across value chains & Consistency \\
\hline & $\begin{array}{l}\text { - Promotion and funding of innovative industrial processes } \\
\text { aiming at the re-use of materials }\end{array}$ & Consistency \\
\hline Consumption & - Increase of trustworthiness of green claims & \\
\hline
\end{tabular}


Sequel to Table 1.

- Enforcement of the rules for green claims Sustainable

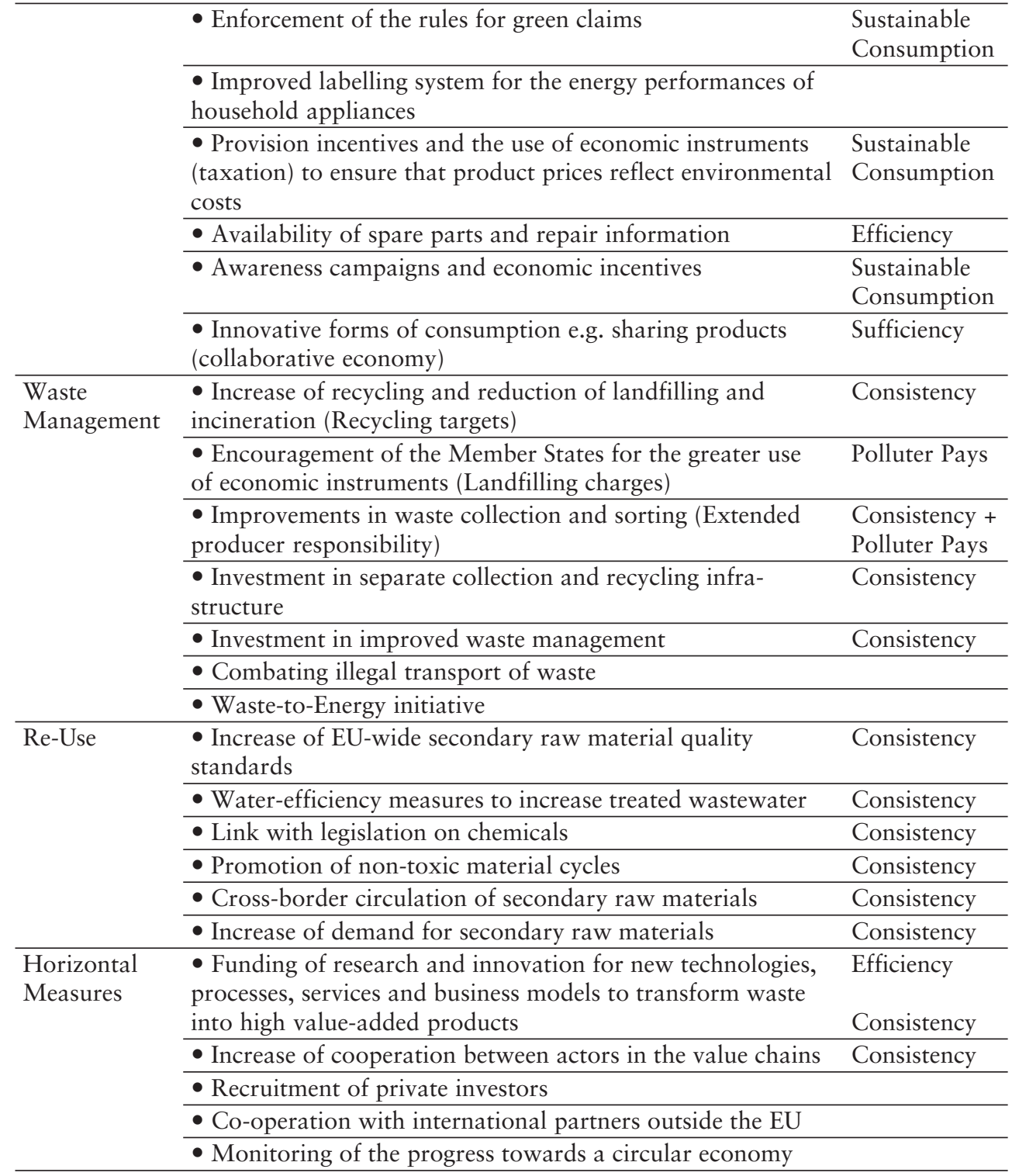

In the single phases of a product's life cycle different sustainability strategies and principles are applied. Concerning production design the EU-Commission generally aims at a longer product life and hence following the efficiency strategy. Alterations in product design and the production process are supposed to increase the recycling- and re-use rate at the end of the lifecycle. Following the consistency strategy a product has already to be designed and produced having the end of its lifecycle in mind. When designing and producing a product, producers have to think from the end. Especially this transformation of the production phase is accompanied by high costs and potentially less monetary turnover for the economy. 
Self-explanatory, the consumption-phase focuses on the consumers and their consumption-behavior. Using measures such as awareness raising and a better information policy, consumption patterns are to be influenced and sustainable consumption is to be increased. What is more, in this phase, the idea of sharing products follows the sufficiency strategy. Applying the consistency strategy, recycling and re-use rates are increased by more effective and innovative waste management. Adding to this, there are economic instruments such as higher fees for non-sustainable methods of waste management such as incineration and landfilling. It is highly advisable that Brussels follows the polluterpays-principle and does not allocate the higher fees on the single consumer. Moreover, the sufficiency strategy is still undervalued.

Re-Use, the core idea of a circular economy, of course has the consistency strategy at its heart. The increase of EU-wide secondary raw material quality standards, crossborder circulation of secondary raw materials and the increase of the demand for secondary raw materials is the realization of the 'from cradle-to-cradle' idea. The horizontal measures also combine efficiency and consistency strategies. While innovation follows both strategies, the cooperation between actors in the value chains clearly focuses on the re-use of products.

In theory, the intended transition towards a circular economy is a promising approach towards a more sustainable future. But, the strategy paper leaves contextual vacancies which EU policy makers alone cannot fill. For such a systemic change Brussels depends on all actors of a product's lifecycle, the EU-Member States and every single consumer. It could turn out to be problematic that the different parties involved in the transformation process usually have different priorities, interests and values. As shown, especially economic and ecological interests still can just be realized at the expense of the other.

\section{A European Strategy for Plastic in a Circular Economy}

As announced in Closing the loop - An EU Action plan for the Circular Economy a communication of the EU-Commission titled A European Strategy for Plastic in a Circular Economy was released on $16^{\text {th }}$ January 2018. It is the first ever Europe-wide strategy on plastics and plastic waste. It is meant to be more far-reaching and more systematic than the 2015 bill mentioned above as it very generally promises that "this strategy lays the foundation to a new plastics economy" (EC, 2018a).

The strategy focuses on six main areas of concern. As a restricting remark, it is to point out that in all of these areas the EU-Commission can only set the framework legislation and function as initiator, financier and supervisory authority. For the actual transformation towards a circular economy and the realization of the plastic strategy, the EU strongly depends on all actors involved in the lifecycle of a product, national and regional authorities and the single consumer. What is more, a successful transformation process of the economy always depends on private investors funding research and innovation. Hence, the actual impact and sustainability of the process towards a circular economy and the plastic strategy is not yet predictable as many different actors and interest groups are involved.

Each chapter covering these six strategic areas contains both, actual measures the EU institutions can realize and implement and suggestions, requests and pleas towards other actors of a product's lifecycle. As these suggestions, requests and pleas are not mandatory, the following table only includes the main measures to be undertaken by the EU. 


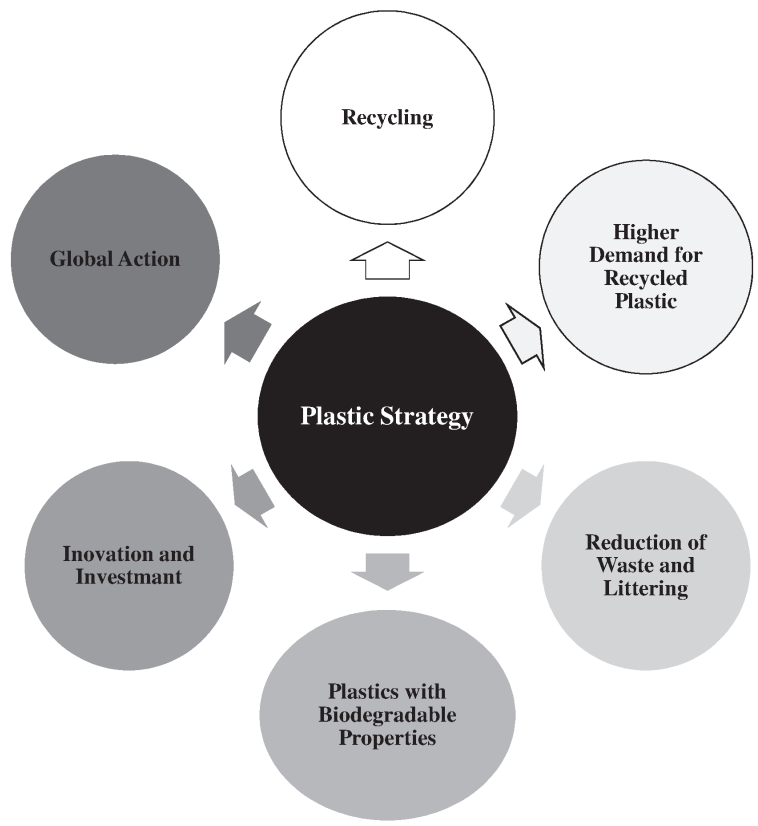

Figure 4. The six areas of the European Strategy for plastics in a circular economy 2018 (EC, 2018a)

Table 2

Overview of the European Strategy for Plastics in a Circular Economy 2018 (EC, 2018a)

\begin{tabular}{|c|c|c|}
\hline Area & Actions & $\begin{array}{l}\text { Principle / } \\
\text { Strategy }\end{array}$ \\
\hline \multirow[t]{5}{*}{ Recycling } & - Product design for increased recyclability & Consistency \\
\hline & - Economic incentives for sustainable design choices & Consistency \\
\hline & - Recycling targets for plastic packaging & \\
\hline & $\begin{array}{l}\text { - Interface between chemicals, waste and product policies to } \\
\text { make it simpler to process or remove chemicals during } \\
\text { recycling }\end{array}$ & Consistency \\
\hline & - Introduction of product requirements fostering recyclability & Consistency \\
\hline \multirow{3}{*}{$\begin{array}{l}\text { Higher } \\
\text { demand for } \\
\text { recycled } \\
\text { plastics }\end{array}$} & $\begin{array}{l}\text { - Introduction of quality standards for sorted plastic waste } \\
\text { and recycled plastics }\end{array}$ & Consistency \\
\hline & $\begin{array}{l}\text { - Greater integration of recycling activities into the plastic } \\
\text { value chain }\end{array}$ & Consistency \\
\hline & - Harmonization of separate collecting and sorting & Consistency \\
\hline \multirow{4}{*}{$\begin{array}{l}\text { Reduction of } \\
\text { waste and } \\
\text { littering }\end{array}$} & $\begin{array}{l}\text { - Extended producer responsibility schemes for single use } \\
\text { plastics, fishing gear and port reception facilities }\end{array}$ & Polluter-Pays \\
\hline & $\begin{array}{l}\text { - EU rules supporting higher recycling rates and better waste } \\
\text { collection systems }\end{array}$ & Consistency \\
\hline & - Bans of certain single use plastic items & Precautionary \\
\hline & - Deposit schemes & Consistency \\
\hline
\end{tabular}


Sequel to Table 2.

\begin{tabular}{|c|c|c|}
\hline & - Awareness campaigns and clean-up projects & $\begin{array}{l}\text { Sustainable } \\
\text { Consumption }\end{array}$ \\
\hline & - Funding of innovative technologies for retrieval & Consistency \\
\hline \multirow{3}{*}{$\begin{array}{l}\text { Plastics with } \\
\text { biodegradable } \\
\text { properties }\end{array}$} & $\begin{array}{l}\text { - Institutionalization of a separate collection system for } \\
\text { organic waste }\end{array}$ & Consistency \\
\hline & $\begin{array}{l}\text { - Introduction of harmonized rules for defining and labelling } \\
\text { compostable and biodegradable plastics }\end{array}$ & Consistency \\
\hline & - Restriction of the use of oxo-plastics in the EU & Precautionary \\
\hline \multirow{5}{*}{$\begin{array}{l}\text { Innovation } \\
\text { and } \\
\text { Investment } \\
\text { towards a } \\
\text { Circular } \\
\text { Solution }\end{array}$} & $\begin{array}{l}\text { - Setting of a framework enabling investment and innovation } \\
\text { by European businesses }\end{array}$ & Consistency \\
\hline & $\begin{array}{l}\text { - Support of the development of alternative feedstocks in } \\
\text { plastic production }\end{array}$ & Consistency \\
\hline & - Acquisition of investors for the recycling industry & Consistency \\
\hline & $\begin{array}{l}\text { - Extended producer responsibility as an incentive to } \\
\text { develop more sustainable plastic products }\end{array}$ & $\begin{array}{l}\text { Polluter-Pays } \\
+ \text { Consistency }\end{array}$ \\
\hline & - Introduction of higher fees for landfilling and incineration & Polluter-Pays \\
\hline \multirow[t]{2}{*}{$\begin{array}{l}\text { Support of } \\
\text { Global Action }\end{array}$} & $\begin{array}{l}\text { - Support of international action and promotion of best } \\
\text { practices worldwide }\end{array}$ & \\
\hline & - Policy dialogues and co-operations & \\
\hline
\end{tabular}

To sum up, the strategy aims at curbing single-use plastics, fishing gear and plastic in general, fostering growth and innovation to transform the way products are designed, produced, used and recycled. At the same time recycling is meant to be made more profitable for the economy to acquire investments from the private sector. Brussels also promises that all plastic packaging on the EU market will be recyclable by 2030 by investing 100 million euros into developing smarter and more recyclable materials. This target is accompanied by the restriction of the intentional use of microplastic and the introduction of a reliable label for biodegradable and compostable plastics. From a global perspective the EU wants to function as a role model for partners all around the world.

Economically speaking, the strategy indirectly also generates advantages. At the moment only $6 \%$ of the value of plastic packaging materials stay in the economy, which means an annual bill accounts between 70 and 105 million euros for the materials lost. Furthermore, energy can be saved as the potential recycling of all global plastic waste would save an equivalent of up to 3.5 billion barrels of oil a year (EC, 2015b).

From a sustainable politics point of view this strategy clearly is more than just symbolic politics as the EU follows a multi-pronged approach. It does not just try to reduce the production and consumption of plastic by setting - often ineffective - fees, national reduction targets or marketing restrictions. The Commission aims at transforming the plastic and recycling industry itself and by doing so the EU attempts to tackle the problem by its roots. Brussels tries to incorporate all actors along a product's lifecycle. Although this approach seems to be the most sustainable choice, it can at the same time lead to a dependency of the EU on actors such as private investors.

From a sustainable development point of view, the strategy contains elements of the precautionary principle such as the ban of single use plastic items. This follows the EU waste hierarchy as its first priority is prevention. But, as Europe and the rest of the world will continue to use different kinds of plastics, recycling, the second priority of 
the waste hierarchy is the predominant approach underlying the strategy. Considering the higher fees for incineration and landfilling and extended producer responsibility schemes, the polluter pays principle is also applied in this communication. In reference to consumer choices, the strategy targets at educational and awareness campaigns to enable the consumer to take sustainable decisions regarding their consumption patterns, which follows the principle of sufficiency. The title of the communication A European Strategy for Plastic in a Circular Economy and the concept of a circular economy itself contain the 'from cradle to cradle' idea. This means that the resources used in a product chain are recycled and then re-injected into a new product life cycle as secondary raw materials. Having this in mind, it does not surprise that the sustainability strategy predominantly used in the analysis of the plastic strategy is Consistency. But, it still remains questionable whether reverse economic and ecological interests can be brought together.

\section{Single Use Plastic Directive}

As a follow up to A European Strategy for Plastic in a Circular Economy a proposal for a directive on the reduction of the impact of certain plastic products on the environment (SUP Directive) was put forward on $28^{\text {th }}$ May 2018 by the European Commission. This proposal mainly focuses on single-use plastic items (SUP). Plastic constitutes 80$85 \%$ of the total number of marine litter items. The amount of plastic marine litter in oceans and seas is still growing and endangers ecosystems, biodiversity and human health. European beach counts show that single-use plastic items are responsible for about half of all marine litter items found on beaches in Europe. The 10 most found single-use plastic items represent $86 \%$ of all items. This means that these 10 items constitute $43 \%$ of all marine litter items found on European beaches. Reasons for this increasing amount of plastic waste are the wide availability of plastic, food consumption outside home and the lack of economic incentives to ensure a proper collection and treatment of waste. So the reasons are linked to the plastic value chain itself and to individual behavior and social trends (EC, 2018c). The communication states that the "the main objective of this initiative is the prevention and reduction of plastic marine litter from single use plastic items [...]" (EC, 2018c). Generally speaking, the Single Use Plastic Proposal is a first step in order to realize the plastic strategy.

On $24^{\text {th }}$ October the European Parliament passed this Single Use Plastic Directive. As the table shows, it includes the complete ban of plates, cutlery, straws, cotton buds and balloon sticks made of plastic from 2021 onwards. From a theoretical point of view, this ban is based on the precautionary principle to prevent littering. The chart also indicates extended producer responsibility for most of the items. For fishing gear and tobacco product filters this means that the respective industry pays for the collection and disposal of the waste produced by them. For these two products the source - the corresponding industry - is held accountable and the polluter pays principle is applied. For all non-restricted items, Brussels also introduces awareness raising measures. This aims at the consumption behavior of the individual to increase sustainable consumption. The single-use nature of these products explains why consistency strategies are of secondary importance in this directive. The measures introduced in this directive will probably prove to be effective concerning single-use plastic items, but they will not trigger the systemic transformation as aimed at in the European strategy for plastic. The actual 
realization and implementation of the European strategy for plastic is still at a very early stage. This constitutes a starting point for further critical analyses and reflection of EU policy-making.

Table 3

Overview of the Single-use Plastic Items and Fishing Gear and the Measures Introduced by the EU-Commission (EC, 2018c)

\begin{tabular}{|c|c|c|c|c|c|c|c|}
\hline & $\begin{array}{l}\text { Consumption } \\
\text { reduction }\end{array}$ & $\begin{array}{c}\text { Market } \\
\text { restriction }\end{array}$ & \begin{tabular}{|c|}
$\begin{array}{c}\text { Product } \\
\text { design } \\
\text { requirement }\end{array}$ \\
\end{tabular} & $\begin{array}{l}\text { Marking } \\
\text { requirements }\end{array}$ & \begin{tabular}{|c|} 
Extended \\
producer \\
responsibility
\end{tabular} & $\begin{array}{l}\text { Separate } \\
\text { collection } \\
\text { objective }\end{array}$ & $\begin{array}{l}\text { Awareness } \\
\text { raising } \\
\text { measures }\end{array}$ \\
\hline Food containers & $\mathrm{x}$ & & & & $\mathrm{x}$ & & $\mathrm{X}$ \\
\hline $\begin{array}{l}\text { Cups for } \\
\text { beverages }\end{array}$ & $\mathrm{x}$ & & & & $\mathrm{x}$ & & $\mathrm{x}$ \\
\hline Cotton bud sticks & & $\mathrm{X}$ & & & & & \\
\hline $\begin{array}{l}\text { Cutlery, plates, } \\
\text { stirrers, straws }\end{array}$ & & $\mathrm{x}$ & & & & & \\
\hline Sticks for balloons & & $\mathrm{X}$ & & & & & \\
\hline Balloons & & & & $\mathrm{X}$ & $\mathrm{X}$ & & $\mathrm{x}$ \\
\hline \begin{tabular}{|l|} 
Packets \& \\
wrappers
\end{tabular} & & & & & $\mathrm{x}$ & & $\mathrm{x}$ \\
\hline $\begin{array}{l}\text { Beverage } \\
\text { containers, their } \\
\text { caps \& lids }\end{array}$ & & & $\mathrm{x}$ & & $\mathrm{x}$ & & $\mathrm{x}$ \\
\hline - Beverage bottles & & & $\mathrm{X}$ & & $\mathrm{X}$ & $\mathrm{X}$ & $\mathrm{X}$ \\
\hline $\begin{array}{l}\text { Tobacco product } \\
\text { filters }\end{array}$ & & & & & $\mathrm{x}$ & & $\mathrm{x}$ \\
\hline $\begin{array}{l}\text { Sanitary items: } \\
\text { - Wet wipes }\end{array}$ & & & & $\mathrm{x}$ & $\mathrm{x}$ & & $\mathrm{X}$ \\
\hline - Sanitary towels & & & & $\mathrm{X}$ & & & $\mathrm{X}$ \\
\hline $\begin{array}{l}\text { Lightweight } \\
\text { plastic carrier bags }\end{array}$ & & & & & $\mathrm{x}$ & & $\mathrm{x}$ \\
\hline Fishing gear & & & & & $\mathrm{X}$ & & $\mathrm{X}$ \\
\hline
\end{tabular}

Topics for Secondary Teaching and Global Developments / Education for Sustainable Development as a Principle of Teaching

The two strategy papers and the two directives of the European commission concerning plastics, plastic waste, maritime litter and recycling outlined above prove that these problems have already been recognized on the political level of the European Union. One the one hand, all communications include awareness raising measures, but, on the other hand, institutions of primary or secondary learning are not specifically mentioned as actors to achieve the aforementioned goals. This is surprising as formal and non-formal education offer effective starting points to generate ecological thinking, sustainable consumption and competences for a self-determined life in a globalized world. To achieve a sustainable change concerning consumption patterns of the individual, institutions of primary and secondary education need to be incorporated into the transformation process towards a circular economy.

As a starting point for the incorporation of educational institutions it is to emphasize that the general topical area plastics with all its subchapters offer numerous topics and didactical approaches for the application in schools of primary and secondary learning. Exemplary topics and possible teaching methods are: 
- Plastics, plastic waste and marine litter - The necessity of supranational legislation for transnational problems and the legislative procedure of the European Union focusing on formal and informal participants. - A model game: Should plastic be forbidden in the EU?

- Microplastic in our food chain - How a car tire ends up in our stomachs. - A product's lifecycle analysis.

- A plastic fork on a journey in a globalized world - Production, consumption, recycling? - A product lifecycle analysis realized as an explanatory video.

- Act locally - think globally: International Coastal Clean-up Day - Preparation, participation and reflection.

While these topics could be allocated to different school subjects such as civic studies, biology or geography, it is preferable that the topics are dealt with by a global development / education for sustainable development approach. This means that a combination of different school subjects systematically attends to the matters at hand using an interdisciplinary approach. This would reach far beyond the selective and isolated treatment of such topics as found in German curricula and schools at the moment.

The special feature of global developments / education for sustainable development as a teaching principle is that it is not just constituted by an integrative corporation of several subjects, but by its interdisciplinary field of study itself and its specific approach to the world. If you want to do justice to the complexity of global developments and globalization, these phenomena cannot be taught by one subject alone. Hence, the introduction of this principle would at the same time mean an enhancement of interdisciplinary teaching with far reaching ramifications for primary and secondary schools (Schreiber \& Siege, 2016). In accordance with Brunold and Ohlmeier, education for a sustainable development is not a new single subject at school, but a principle for teaching adapted to the global situation of the $21^{\text {st }}$ century. It does not want to suspend traditional learning, but to impart competences to help the individual to orient him- / herself in a globalized world (Ohlmeier \& Brunold, 2015).

\section{Competences of Global Developments / The Education for Sustainable Development}

The German Kultusministerkonferenz, a commission of all 16 Ministers of Education of the 16 German federal states, published a frame of orientation concerning global developments / the education for sustainable development. In this publication the commission defines three umbrella-categories of competences: Realize - Assess - Act. These three umbrella-competencies are separate but complementary components of a holistic concept of competence. Competencies are defined as preferable behavior patterns of pupils. The separation between these three categories does not imply a strict didactical one-afterthe other succession when realizing them in actual teaching (Schreiber \& Siege, 2016).

The competence Realize aims at target-oriented knowledge acquisition. This means the ability to research and construct knowledge for numerous topical areas. The umbrella category Assess includes critical reflection and the recognition and balancing of different values and courses of action; both are prerequisites of the umbrella-competence Act. Generally speaking, Act describes the disposition to harmonize one's behavior with a sustainable way of life (Schreiber \& Siege, 2016). These three umbrella categories are further defined as core-competencies as depicted in the following table: 
- Information procurement and processing focusing on

- Analysis of global developments from a sustainable point of view

- Differentiation between possible level of actions - from the individual to the world

Assess

- Empathy and the change of perspective concerning values and life styles

- Critical reflection and evaluation of global developments

\section{Act}

- Solidarity and responsibility for humankind and the environment

- The ability to act in a globalized world

- Participation in a globalized world

Figure 5. Competences of global developments / the education for sustainable development (Schreiber \& Siege, 2016)

One can further break down these core-competencies into subject- and topic-related competencies, which again are in the service of these core competences. Although this model strongly focuses on competences, it is clear that actual factual knowledge is of vital importance - even in competence orientated learning processes. One cannot knit without wool. In the end, competences can be defined as characteristics of a person which manifest themselves in actions (Ohlmeier \& Brunold, 2015).

Following these core-competencies education for sustainable development also aims at learning processes which support pupils in constructing, assessing and applying their knowledge. Methods for the concrete instructional realization at institutions for secondary school education are for example methods of participation such as workshops for future scenarios or model games, among others (Ohlmeier \& Brunold, 2015). While all these methods are established interdisciplinary approaches of civic education, the topics introduced above suggest that the methodology of the field of economics can also be fruitfully applied for an education for sustainable development. This approach also constitutes a starting point for further research.

The publication of the framework for global developments / the education for sustainable development by the German Kultusministerkonferenz shows that there is at least some political impetus for the implementation of this topic area and teaching principle at the national level. But - looking at the curricula of the sixteen German federal states and the reality in German classrooms it becomes obvious that these topics have not yet received the attention they deserve and the teaching principle is put into practice very rudimentarily. This is the more surprising as these issues are key problems present and future generations will have to deal with, their implementation is demanded by the UN Decade of Education for Sustainable Development and the intended teaching principle promises substantial skill acquisition and the expansion of several key competences. Generally speaking, facing climate change as a key issue of the $21^{\text {st }}$ century, this teaching principle needs to be strengthened. 


\section{Conclusion}

The attempt to advance the transformation of the EU economy towards a circular economy and the plastic strategy show that the EU tries to work towards a more sustainable future. Principally, the strategy papers and directives follow sustainable development principles such as consistency and efficiency; sufficiency is just of secondary nature. Concerning the alteration of consumption patterns, Brussels relies on more reliable information, awareness-raising and educational measures. Apparently, the EU Commission confides in the maturity of the consumer and does not intend to introduce further reaching restrictions regarding the consumption or the production of plastics and plastic products. Brussels rather hopes for a self-transformation of the plastic and recycling industry accompanied by funding and innovations carried out by the private sector without having much more influence than setting the framework conditions. The transformation towards a circular economy will most likely be accompanied by a clash of economic and ecological interests such as profit maximization and the durability and repairability of a product.

Focusing on education, the topical area plastics, plastic waste and marine litter contains broad substantial, didactical and methodological potential for the education for sustainable development at institutions of primary and secondary education which is not nearly exploited enough so far. To accelerate the transformation process towards a more sustainable future, educational institutions need to be actively incorporated into this process and the education for sustainable development needs to be strengthened.

\section{References}

European Commission (EC). (2008). Directive 2008/98/EC on waste. Retrieved from http://ec.europa.eu/environment/waste/framework/

European Commission (EC). (2013). How can we reduce marine litter? Retrieved from http://europa.eu/rapid/press-release_IP-13-976_en.htm

European Commission (EC). (2015a). Directive (EU) 2015/720. Retrieved from https://publications.europa.eu/en/publication-detail/-/publication/58d93aee-f3bc11e4-a3bf-01aa75ed71a1/language-en

European Commission (EC). (2015b). Closing the loop - An EU action plan for the Circular Economy. Retrieved from https:/eur-lex.europa.eu/legal-content/EN/TXT/ HTML/?uri=CELEX:52015DC0614\&from=EN

European Commission (EC). (2018a). A European Strategy for Plastics in a Circular Economy. Retrieved from https://eur-lex.europa.eu/resource.html? uri=cellar:2df5d 1d2-fac7-11e7-b8f5-01aa75ed71a1.0001.02/DOC_1\&format=PDF

European Commission (EC). (2018b). Communication from the Commission to the European Parliament, the Council, the European economic and social committee and the committee of the regions on a monitoring framework for the circular economy. Retrieved from http://ec.europa.eu/environment/circular-economy/pdf/ monitoring-framework.pdf

European Commission (EC). (2018c). Directive of the European Parliament and of the Council on the reduction of the impact of certain plastic products on the environment. Retrieved from https://eur-lex.europa.eu/resource.html?uri=cellar:fc $5 \mathrm{c} 74 \mathrm{e} 0$ 6255-11e8-ab9c-01aa75ed71a1.0002.02/DOC_1\&format=PDF 
Ohlmeier, B., \& Brunold, A. (2015). Politische Bildung für nachhaltige Entwicklung: Eine Evaluationsstudie [Civic Education for sustainable development - an evaluation study]. Wiesbaden: Springer VS Research.

Schreibe, J. R., \& Siege, H. (2016). Orientierungsrahmen für den Lernbereich Globale Entwicklung im Rahmen einer Bildung für nachhaltige Entwicklung [Global development education. A cross-curricular framework in the context of education for sustainable development]. Bonn: Cornelsen.

Wiepcke, C. (2007). Planspiel [Modle Games]. In S. Reindhardt (Ed.). Politik-Methodik: Handbuch für die Sekundarstufe I und II [Civic education methodology: compendium for secundary education I and II], 63-68. Berlin: Cornelsen Scriptor.

Correspondence regarding this article should be addressed to Ulrich Kerscher, University of Augsburg, Germany. Email: ulrich.kerscher@phil.uni-augsburg.de 